\title{
A study on $\mathrm{N}_{2} \mathrm{O}$ catalytic decomposition over $\mathrm{Co} / \mathrm{MgO}$ catalysts
}

\author{
Qun Shen, Landong Li, Jinjun Li, Hua Tian, Zhengping Hao* \\ Department of Environmental Nano-materials, Research Center for Eco-Environmental Sciences, Chinese Academy of Sciences, Beijing 100085, PR China
}

\section{A R T I C L E I N F O}

\section{Article history:}

Received 10 May 2008

Received in revised form 24 July 2008

Accepted 24 July 2008

Available online 31 July 2008

\section{Keywords:}

$\mathrm{Co} / \mathrm{MgO}$

$\mathrm{N}_{2} \mathrm{O}$ decomposition

Control of greenhouse gas

\begin{abstract}
A B S T R A C T
Different oxide supported cobalt catalysts were prepared by co-precipitation method and tested for the decomposition of nitrous oxide. $\mathrm{Co} / \mathrm{MgO}$ with cobalt loading of $15 \%$ showed the best activity and a $100 \% \mathrm{~N}_{2} \mathrm{O}$ conversion was obtained at temperatures higher than $700 \mathrm{~K}$. The active phase of cobalt species in $\mathrm{Co} / \mathrm{MgO}$ catalysts was $\mathrm{CO}_{3} \mathrm{O}_{4}$ highly dispersed in the matrices of $\mathrm{MgO}$, based on XRD and XPS results as well as the kinetic analysis. The existence of $\mathrm{NO}, \mathrm{O}_{2}$ and $\mathrm{H}_{2} \mathrm{O}$ in reaction system showed different negative effects on $\mathrm{N}_{2} \mathrm{O}$ decomposition. Nevertheless, a $100 \% \mathrm{~N}_{2} \mathrm{O}$ conversion could be achieved at $800 \mathrm{~K}$ under simulated conditions of tail gas from nitric acid plant. Moreover, $\mathrm{Co} / \mathrm{MgO}$ catalyst exhibited quite good durability and no obvious activity loss was observed in the $100 \mathrm{~h}$ stability test.
\end{abstract}

(c) 2008 Elsevier B.V. All rights reserved.

\section{Introduction}

For a long time, nitrous oxide $\left(\mathrm{N}_{2} \mathrm{O}\right)$ had been considered as a relatively harmless gas and not received much attention from the viewpoint of environmental pollutants. However, since the last decade, $\mathrm{N}_{2} \mathrm{O}$ has been recognized as a strong greenhouse gas and also severely destructs the ozone in the stratosphere [1]. $\mathrm{N}_{2} \mathrm{O}$ has a very long atmospheric lifetime ( $\sim 120$ years), the global warming potential (GWP) of nitrous oxide $\left(\mathrm{N}_{2} \mathrm{O}\right)$ is about 310 times of carbon dioxide $\left(\mathrm{CO}_{2}\right)$ [2]. Anthropogenic $\mathrm{N}_{2} \mathrm{O}$ emissions mainly come from chemical industries, e.g. the production of nitric acid and organic synthesis employing nitric oxidation process (production of adipic acid and glyoxal). Several end-of-pipe technologies have been developed to mitigate $\mathrm{N}_{2} \mathrm{O}$ emission from above anthropogenic sources and amongst these different technologies, the catalytic decomposition is proposed as the most economical method. However, for $\mathrm{N}_{2} \mathrm{O}$ catalytic decomposition, catalysts should possess a sufficient activity and durability.

Various types of catalysts, e.g. supported noble metals [3-5], mixed oxides with different structure [6-10], iron zeolites [11-15], have been investigated for $\mathrm{N}_{2} \mathrm{O}$ decomposition. Supported cobalt catalysts have received considerable attention due to high activity [16-26]. da Cruz et al. [16] reported the studies of $\mathrm{N}_{2} \mathrm{O}$ decomposition on Co-ZSM-5 prepared with different methods and claimed that isolated $\mathrm{Co}^{2+}$ ions showed high activity. Kannan and Swamy

\footnotetext{
* Corresponding author. Tel.: +86 10 62849194; fax: +861062923564.

E-mail address: zpinghao@rcees.ac.cn (Z. Hao).
}

[18] studied $\mathrm{N}_{2} \mathrm{O}$ decomposition over calcined cobalt aluminum catalyst and found that the activity increased with the increasing cobalt concentration. Chellam et al. [19] and Yan et al. [20] reported that $\mathrm{Co}_{3} \mathrm{O}_{4}$ spinel with the addition of another kind of transition metal $\left(\mathrm{M}_{x} \mathrm{Co}_{1-x} \mathrm{Co}_{2} \mathrm{O}_{4}, \mathrm{M}=\mathrm{Ni}, \mathrm{Mg}\right)$ were very active for $\mathrm{N}_{2} \mathrm{O}$ decomposition, even at reaction temperatures below $400^{\circ} \mathrm{C}$. However, the high activity of catalysts seems to depend much on the preparation parameters [19]. Recently, $\mathrm{MgCo}_{2} \mathrm{O}_{4}$ was reported to have the best activity for $\mathrm{N}_{2} \mathrm{O}$ decomposition by Russo et al. [21]. A $100 \% \mathrm{~N}_{2} \mathrm{O}$ conversion was achieved on the $\mathrm{MgCo}_{2} \mathrm{O}_{4}$ (spineltype $\mathrm{AB}_{2} \mathrm{O}_{4}$ ) catalyst at higher than $500^{\circ} \mathrm{C}$ in the absence of oxygen. Obalová et al. [22,23] presented a detailed study on $\mathrm{N}_{2} \mathrm{O}$ decomposition over spinel catalysts prepared from $\mathrm{Co} / \mathrm{Mg}-\mathrm{Mn} / \mathrm{Al}$ hydrotalcite-like compounds and found Mn/Al ratio played a key role on the activity. For most studies on supported cobalt catalysts for $\mathrm{N}_{2} \mathrm{O}$ decomposition, the high activity of catalysts was severely affected by the addition of oxygen and water vapor to the feed gas. [24].

However, to-date, the active phase for $\mathrm{N}_{2} \mathrm{O}$ decomposition in the $\mathrm{Co} / \mathrm{MgO}$ catalyst is not adequately understood. And the activity under simulated conditions at the typical nitric acid plant has not been presented yet considering the future application. During our research on potential catalyst for $\mathrm{N}_{2} \mathrm{O}$ decomposition, we also found that $\mathrm{Co} / \mathrm{MgO}$ samples prepared by simple co-precipitation method showed remarkably activity. In this work, a detailed study is presented concerning the following aspects: (i) characterization of active phase of cobalt species in $\mathrm{Co} / \mathrm{MgO}$ for $\mathrm{N}_{2} \mathrm{O}$ decomposition; (ii) the activity and durability of $\mathrm{Co} / \mathrm{MgO}$ catalysts for $\mathrm{N}_{2} \mathrm{O}$ decomposition under different reaction conditions. 


\section{Experimental}

\subsection{Catalyst preparation}

The Co-based catalysts were prepared with co-precipitation method. In a typical synthesis, cobalt nitrate and magnesium (or zinc, manganese, aluminum, cerium) nitrate were mixed with various metal mole ratio (fixing the cobalt loading) in $200 \mathrm{~mL}$ distilled water. The precipitator ( $1 \mathrm{M} \mathrm{Na}_{2} \mathrm{CO}_{3}$ solution) was added drop-wise into the as-prepared mixed-metal nitrate aqueous solution under vigorous magnetic stirring with $180 \mathrm{rpm}$ until the $\mathrm{pH}$ of mother liquor reached about 9.0. After aging in the suspension for $2 \mathrm{~h}$ under stirring at room temperature, precipitates were collected by filtration and thoroughly washed with distilled water. The cake was dried at $353 \mathrm{~K}$ overnight and then calcined in air at $773 \mathrm{~K}$ for $6 \mathrm{~h}$ to derive the corresponding oxides. The cobalt loadings in $\mathrm{Co} / \mathrm{ZnO}$, $\mathrm{Co} / \mathrm{Mn}_{x} \mathrm{O}_{y}, \mathrm{Co} / \mathrm{Al}_{2} \mathrm{O}_{3}$ and $\mathrm{Co} / \mathrm{CeO}_{2}$ were designed to be $10 \%$, which were confirmed by ICP analysis. For $\mathrm{Co} / \mathrm{MgO}$, samples with different cobalt loadings were prepared, which were denoted as $\mathrm{Co} / \mathrm{MgO}-5 \%$, $\mathrm{Co} / \mathrm{MgO}-10 \%$, $\mathrm{Co} / \mathrm{MgO}-15 \%$ and $\mathrm{Co} / \mathrm{MgO}-20 \%$.

\subsection{Catalyst characterizations}

The cobalt loadings of supported cobalt catalysts were determined by ICP-AES using an Optima 2000 spectrometer. Low temperature $\mathrm{N}_{2}$ adsorption/desorption experiments of catalysts samples were carried out in a Quantachrome NOVA-1200 gas absorption analyzer, and the specific surface area was calculated with BET equation.

The X-ray diffraction (XRD) patterns of samples were measured on a Rigaku powder diffractometer (D/MAX-RB) using $\mathrm{Cu} K \alpha$ radiation $(\lambda=0.15418 \mathrm{~nm})$ at a scanning rate of $4^{\circ} / \mathrm{min}$ in $2 \theta=5-80^{\circ}$.

Transmission electron microscopy images of sample were acquired on a JEOL 3010 transmission electron microscope at an accelerate voltage of $300 \mathrm{kV}$. A few droplets of the sample suspended in alcohol were placed on a carbon-coated copper grid followed by evaporation at ambient conditions.

XPS (X-ray photoelectron spectroscopy) measurement of selected catalysts was carried out in a VG-Microtech Multilab electron spectrometer using $\mathrm{Mg} \mathrm{K \alpha}(1253.6 \mathrm{eV})$ radiation source. The analysis chamber was maintained at $5 \times 10^{-10} \mathrm{mbar}$ and the binding energy was adjusted by setting the $\mathrm{C} 1 \mathrm{~s}$ transition at $284.6 \mathrm{eV}$.

\subsection{Activity evaluation and kinetics studies}

$\mathrm{N}_{2} \mathrm{O}$ decomposition experiments were performed in a fixed-bed flow microreactor at atmospheric pressure. For each run, $0.1 \mathrm{~g}$ catalyst (sieve fraction, $0.25-0.5 \mathrm{~mm}$ ) was placed into a quartz reactor ( $4 \mathrm{~mm}$ i.d.) and pretreated in He at $773 \mathrm{~K}$ for $1 \mathrm{~h}$. After the reactor was cooled to $473 \mathrm{~K}$, the reactant gas mixture was fed into the reactor. The total flowing rate of inlet gas was set at $60 \mathrm{~mL} \mathrm{~min}^{-1}$, corresponding to GHSV $=30000 \mathrm{~h}^{-1}$. The gas composition was analyzed on-line using a gas chromatograph (Agilent 6820 series) equipped with a TCD detector and two serial columns (a Porapak $\mathrm{Q}$ column served for the separation of $\mathrm{N}_{2} \mathrm{O}$ and the mixture of $\mathrm{N}_{2} / \mathrm{O}_{2}$, and a molecular sieve $5 \mathrm{~A}$ column for the separation of $\mathrm{N}_{2}$ and $\mathrm{O}_{2}$ ). The steady-state activity data were recorded every $25 \mathrm{~K}$ at ascending temperature from $473 \mathrm{~K}$ to $773 \mathrm{~K}$ (for activity test) or at a constant temperature (for durability test).

Furthermore, the first-order rate constant $(k)$, the activation energy $\left(E_{\mathrm{a}}\right)$ were calculated. Based on the assumption of first-order reaction for $\mathrm{N}_{2} \mathrm{O}$ decomposition, the rate of $\mathrm{N}_{2} \mathrm{O}$ decomposition can be recognized as

$r=k P_{\mathrm{N}_{2} \mathrm{O}}=A \mathrm{e}^{-E_{\mathrm{a}} / R T} P_{\mathrm{N}_{2} \mathrm{O}}$
Pseudo-first-order rate constants were calculated using the formula [27]:

$k=-\frac{\ln (1-x) F}{m_{\text {cat }} P}$

Where $x$ is the $\mathrm{N}_{2} \mathrm{O}$ conversion, $F$ is the total flow through the reactor, $P$ is the total pressure, $m_{\text {cat }}$ is the amount of the catalyst, $T$ is the temperature. The plot of $\ln (k)$ versus $1 / T$ was drawn according to the data collected from steady-state reaction. The slope of this plot represents the apparent activation energy, and the intercept represents associated pre-exponential factor.

\section{Results and discussion}

\subsection{Characterization results}

The XRD patterns of supported cobalt catalysts, with the same cobalt loading of 10\%, are displayed in Fig. 1. It is seen that a mixture of unitary metal oxides or binary metal oxides phases are observed in the XRD patterns except the $\mathrm{Co} / \mathrm{MgO}$ catalyst. For example, $\mathrm{CO}_{3} \mathrm{O}_{4}$ and $\mathrm{CeO}_{2}$ are observed for $\mathrm{Co} / \mathrm{CeO}_{2}$ sample, $\mathrm{CoAl}_{2} \mathrm{O}_{4}$ and $\mathrm{Al}_{2} \mathrm{O}_{3}$ for $\mathrm{Co} / \mathrm{Al}_{2} \mathrm{O}_{3}, \mathrm{CoMnO}_{3}$ and $\mathrm{Mn}_{2} \mathrm{O}_{3}$ for $\mathrm{Co} / \mathrm{Mn}_{x} \mathrm{O}_{y}, \mathrm{Zn}_{x} \mathrm{Co}_{1-x} \mathrm{Co}_{2} \mathrm{O}_{4}$ and $\mathrm{ZnO}$ for $\mathrm{Co} / \mathrm{ZnO}$. The main diffraction peaks are identified (Fig. 1), and diffraction peaks corresponding to other structures are not discussed here due to their low intensity. While in the XRD pattern of $\mathrm{Co} / \mathrm{MgO}$, only ( $\mathrm{Co} / \mathrm{Mg}) \mathrm{O}$ phase (JCPDS 02-1201) are observed and no other diffraction peaks corresponding to other species are found.

Fig. 2 shows the XRD pattern for the $\mathrm{Co} / \mathrm{MgO}$ catalysts with different cobalt loading. Only ( $\mathrm{Co} / \mathrm{Mg}) \mathrm{O}$ phase are observed for $\mathrm{Co} / \mathrm{MgO}$ with cobalt loading below $15 \%$. As for $\mathrm{Co} / \mathrm{MgO}-20 \%$, besides the $(\mathrm{Co} / \mathrm{Mg}) \mathrm{O}$ phase, diffraction peaks corresponding to cobalt oxides (marked with *) appear.

The BET surface areas of supported cobalt catalysts are listed in Table 1. It is seen that $\mathrm{Co} / \mathrm{MgO}$ shows much higher surface $\left(179.5 \mathrm{~m}^{2} / \mathrm{g}\right)$ than other Co-based samples $\left(22.6-53.5 \mathrm{~m}^{2} / \mathrm{g}\right)$ with similar cobalt loadings of $10 \%$. Considering the XRD results, it is concluded the formation of bulk cobalt oxides or composite oxides leads to distinct decrease in surface area. The surface area

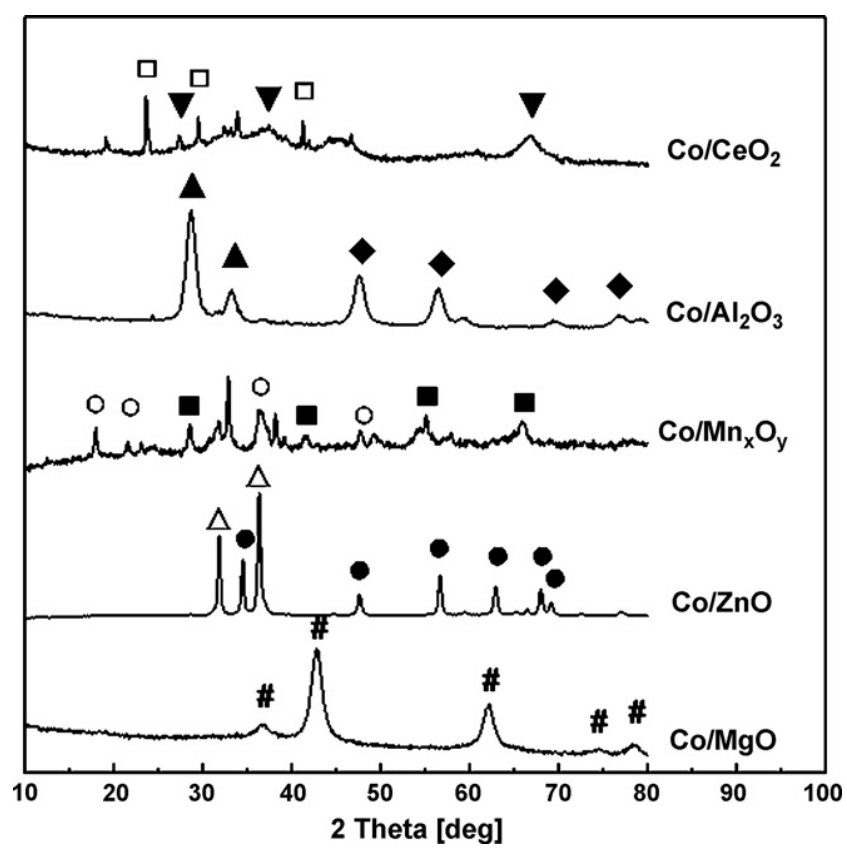

Fig. 1. XRD patterns of Co-based catalysts. ( $\square)-\mathrm{CeO}_{2} ;(\boldsymbol{v})-\mathrm{Co}_{3} \mathrm{O}_{4} ;(\boldsymbol{\Lambda})-\mathrm{CoAlO}_{2}$; ( $\left.\square\right)-$ $\mathrm{Al}_{2} \mathrm{O}_{3}$; (○)- $\mathrm{Mn}_{2} \mathrm{O}_{3}$; ( $)-\mathrm{CoMnO}_{3}$; $(\square)-\mathrm{ZnO} ;(\bullet)-\mathrm{Zn}_{x} \mathrm{Co}_{3-x} \mathrm{O}_{4}$; (\#)- (Co,Mg)O. 


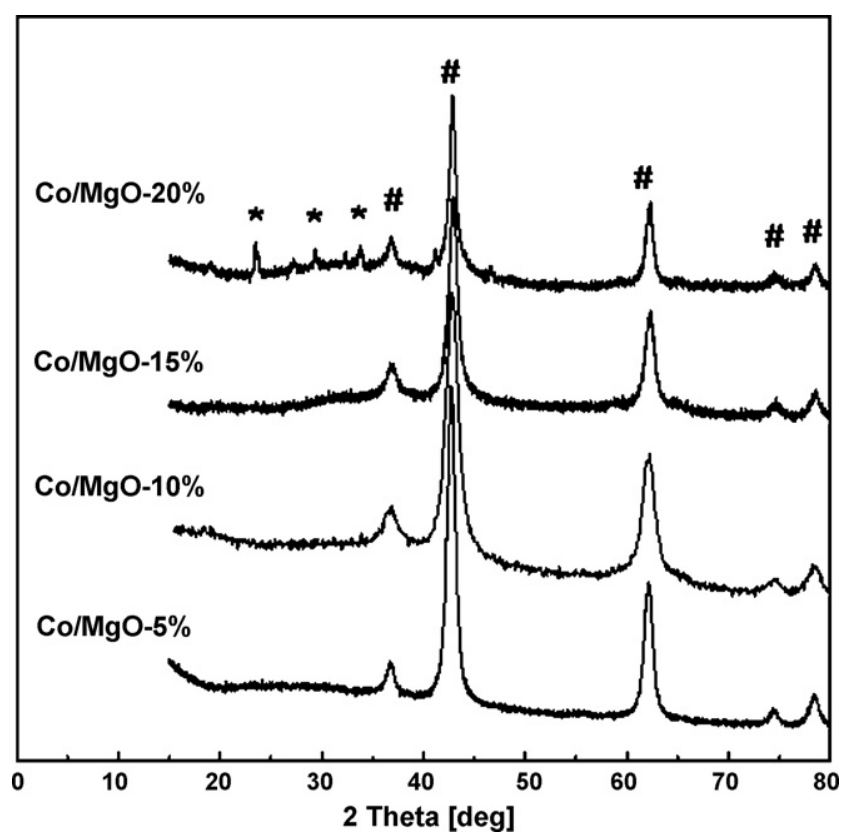

Fig. 2. XRD patterns of $\mathrm{Co} / \mathrm{MgO}$ samples with different Co loadings. (\#) -(Co,Mg)O, $\left({ }^{*}\right)-\mathrm{CO}_{3} \mathrm{O}_{4}$.

of $\mathrm{Co} / \mathrm{MgO}-5 \%$ sample $\left(177.7 \mathrm{~m}^{2} / \mathrm{g}\right)$ is quite similar to $\mathrm{Co} / \mathrm{MgO}-10 \%$ while the surface area of $\mathrm{Co} / \mathrm{MgO}-20 \%$ is much lower $\left(25.1 \mathrm{~m}^{2} / \mathrm{g}\right)$, due to the formation of cobalt oxides, which is also proved by the XRD results. For $\mathrm{Co} / \mathrm{MgO}-15 \%$, even though no other phase besides ( $\mathrm{Co} / \mathrm{Mg}) \mathrm{O}$ periclase can be found in the XRD pattern, a lower surface area of $112.2 \mathrm{~m}^{2} / \mathrm{g}$ are obtained.

The TEM image for $\mathrm{Co} / \mathrm{MgO}-15 \%$ in Fig. 3 shows the morphology of lamella. It is known that this kind of morphology is the characterized morphology of hydrotalcite [28]. The morphology of hydrotalcite-like precursor is well preserved after calcination, and cobalt oxides should evenly disperse in the MgO oxide matrices, which is consistent with the XRD results.

The surface electronic states of cobalt in $\mathrm{Co} / \mathrm{MgO}$ samples were examined by means of XPS. As seen in Fig. 4 , the position of Co $2 \mathrm{p}_{3 / 2}$ for all samples is $779.9 \mathrm{eV}$, while the position of Co $2 \mathrm{p}_{1 / 2}$ is $795.5 \mathrm{eV}$. It is thus confirmed that cobalt exists in the form of $\mathrm{CO}_{3} \mathrm{O}_{4}$ in matrices of $\mathrm{MgO}$ [29], and no difference in the electronic state with cobalt loading of 5-15\%. This suggests the uniformity and good dispersion of Co species in $\mathrm{Co} / \mathrm{MgO}$. The analysis of $\mathrm{O}$ 1s peak in XPS spectra shows us additional information on the samples. As seen in Fig. 4, two contributions arise at 529.2 and $530.8 \mathrm{eV}$ on the $\mathrm{O}$ 1s peak, which can be assigned to lattice oxygen in oxides and OH groups on the surface [30,31], respectively. Abundant surface $\mathrm{OH}$ groups exist in $\mathrm{Co} / \mathrm{MgO}$ catalysts, most probably between the lamella structures.

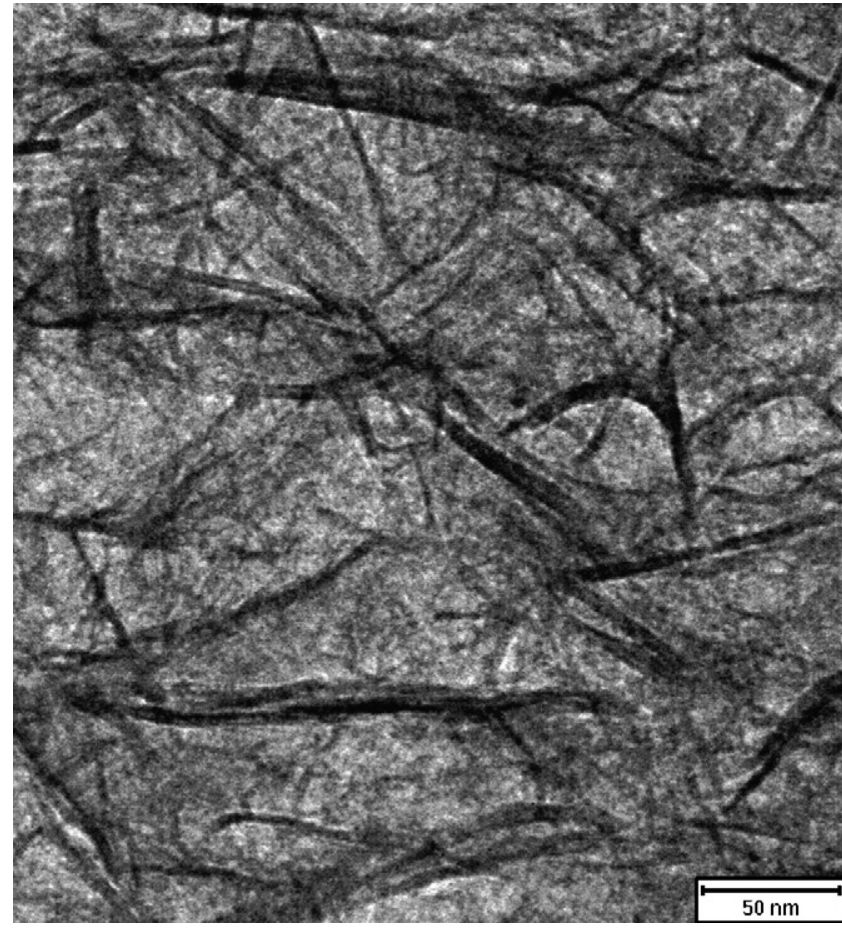

Fig. 3. TEM image of $\mathrm{Co} / \mathrm{MgO}-15 \%$.

\subsection{Catalytic activities for $\mathrm{N}_{2} \mathrm{O}$ decomposition}

Fig. 5 shows the catalytic activities for $\mathrm{N}_{2} \mathrm{O}$ decomposition over Co-based catalysts with cobalt loadings of $10 \%$. The activity is observed as $\mathrm{Co} / \mathrm{MgO}>\mathrm{Co} / \mathrm{ZnO}>\mathrm{Co} / \mathrm{Mn}_{x} \mathrm{O}_{y}>\mathrm{Co} / \mathrm{Al}_{2} \mathrm{O}_{3}>\mathrm{Co} / \mathrm{CeO}$. For the best $\mathrm{Co} / \mathrm{MgO}$ catalyst, the reaction temperature attained 50 and $100 \% \mathrm{~N}_{2} \mathrm{O}$ conversion was around 675 and $750 \mathrm{~K}$, respectively. The activity is comparable with other Co-based catalysts, over which a $100 \% \mathrm{~N}_{2} \mathrm{O}$ conversion was attained mostly in the temperature range of 700-773 K [19-21,25,26]. The TPR results of cobalt in different supports (not shown here) exhibit that there are no direct relationship between the redox property of cobalt and the catalytic activity. While from the distinction of appreciable activity for Co-based catalysts studied, it is clear that the supports play an important role on catalytic activity for $\mathrm{N}_{2} \mathrm{O}$ decomposition. The alkaline $\mathrm{MgO}$ clearly appears to be good support for active cobalt species. We suppose that $\mathrm{MgO}$ as a support is propitious to the dispersion of the active cobalt species, which is proved by the XRD and BET results. Furthermore, it is well known that the initial step for $\mathrm{N}_{2} \mathrm{O}$ decomposition is the breaking of $\mathrm{N}-\mathrm{O}$ bond by filling electrons into the $3 \pi$ anti-bonding orbital [32]. And $\mathrm{MgO}$, as a support with strong electron donation, is favorable for the electron transformation. We suppose that during $\mathrm{N}_{2} \mathrm{O}$ decomposition, the electrons transfer from $\mathrm{MgO}$ to the $\mathrm{Co}_{3} \mathrm{O}_{4}$ and thus promote the activation

Table 1

Kinetic parameters for $\mathrm{N}_{2} \mathrm{O}$ decomposition over supported cobalt catalysts

\begin{tabular}{|c|c|c|c|c|}
\hline Sample & BET area $\left(\mathrm{m}^{2} / \mathrm{g}\right)$ & Coloading (wt\%) & Activation energy $(\mathrm{kJ} / \mathrm{mol})$ & Pre-exponential factor $\left(\mathrm{mol} \mathrm{N}_{2} \mathrm{O} / \mathrm{s} \mathrm{mol} \mathrm{Co} \mathrm{PaN}_{2} 0\right)$ \\
\hline $\mathrm{Co} / \mathrm{CeO}_{2}-10 \%$ & 46.7 & 9.86 & 127.4 & 74.5 \\
\hline $\mathrm{Co} / \mathrm{Al}_{2} \mathrm{O}_{3}-10 \%$ & 53.5 & 10.14 & 89.7 & 4.76 \\
\hline $\mathrm{Co} / \mathrm{MnO}_{2}-10 \%$ & 33.4 & 9.78 & 78.5 & 3.52 \\
\hline $\mathrm{Co} / \mathrm{ZnO}-10 \%$ & 22.6 & 9.96 & 76.1 & 1.67 \\
\hline $\mathrm{Co} / \mathrm{MgO}-10 \%$ & 179.5 & 9.86 & 73.1 & 2.41 \\
\hline $\mathrm{Co} / \mathrm{MgO}-5 \%$ & 177.7 & 4.85 & 73.5 & 1.07 \\
\hline $\mathrm{Co} / \mathrm{MgO}-15 \%$ & 122.2 & 14.64 & 72.9 & 3.68 \\
\hline $\mathrm{Co} / \mathrm{MgO}-20 \%$ & 35.1 & 19.32 & 77.5 & 5.48 \\
\hline $\mathrm{CO}_{3} \mathrm{O}_{4}$ & 25.7 & 100 & 73.9 & 4.87 \\
\hline
\end{tabular}



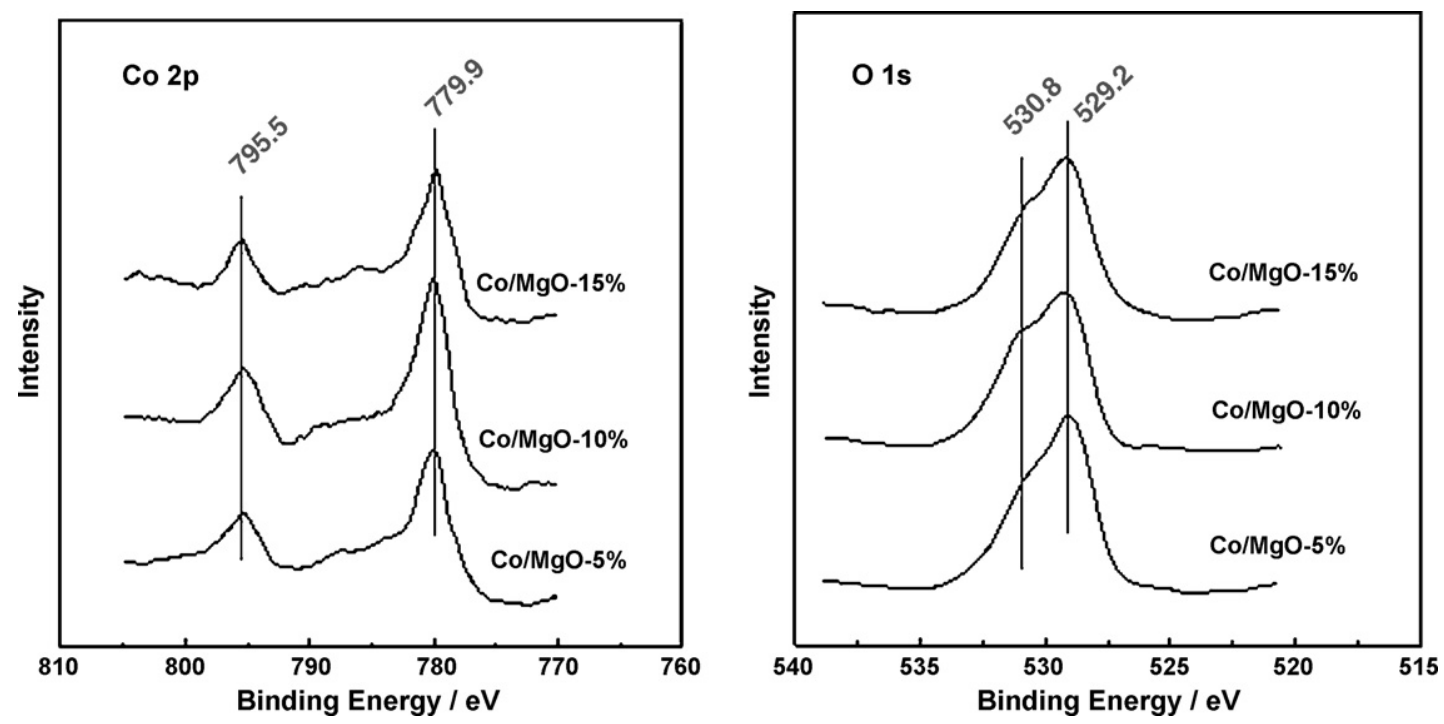

Fig. 4. XPS of $\mathrm{Co} 2 \mathrm{p}$ and $\mathrm{O} 1 \mathrm{~s}$ for $\mathrm{Co} / \mathrm{MgO}$ samples with different $\mathrm{Co}$ loadings.

of $\mathrm{N}_{2} \mathrm{O}$ on cobalt species, similar to ammonia synthesis on $\mathrm{Ru}-\mathrm{Ba} / \mathrm{C}$ catalyst [33].

We further study the effect of cobalt loadings on the catalytic activities of $\mathrm{Co} / \mathrm{MgO}$ samples. As seen in Fig. 6, Co/MgO-20\% and $\mathrm{Co} / \mathrm{MgO}-15 \%$ show similar higher activity, followed by $\mathrm{Co} / \mathrm{MgO}-10 \%$ and then $\mathrm{Co} / \mathrm{MgO}-5 \%$. The activity increases with raise cobalt loadings from 5 to $15 \%$. However, further raise in cobalt loading to $20 \%$ does not result in corresponding activity increased, probably due to the formation of new cobalt oxides phases. Moreover, the activity of pure $\mathrm{Co}_{3} \mathrm{O}_{4}$ is found to be lower than $\mathrm{Co} / \mathrm{MgO}-10 \%$ but higher than $\mathrm{Co} / \mathrm{MgO}-5 \%$. The Arrhenius plots of $\mathrm{N}_{2} \mathrm{O}$ decomposition on $\mathrm{Co} / \mathrm{MgO}$ with different cobalt loadings are shown in Fig. 7. Similar apparent activation energies $\left(72.9-73.9 \mathrm{~kJ} / \mathrm{mol}\right.$ ) are obtained for pure $\mathrm{Co}_{3} \mathrm{O}_{4}$ and $\mathrm{Co} / \mathrm{MgO}$ samples with cobalt loadings of $5-15 \%$ (Table 1 ) and accordingly their activity difference is caused by the different preexponential factor. In contrast, the apparent activation energy of $\mathrm{Co} / \mathrm{MgO}-20 \%$ is much higher $(77.5 \mathrm{~kJ} / \mathrm{mol})$ compared to $\mathrm{Co} / \mathrm{MgO}$ samples with cobalt loadings of $5-15 \%$. It is thus indicated that the

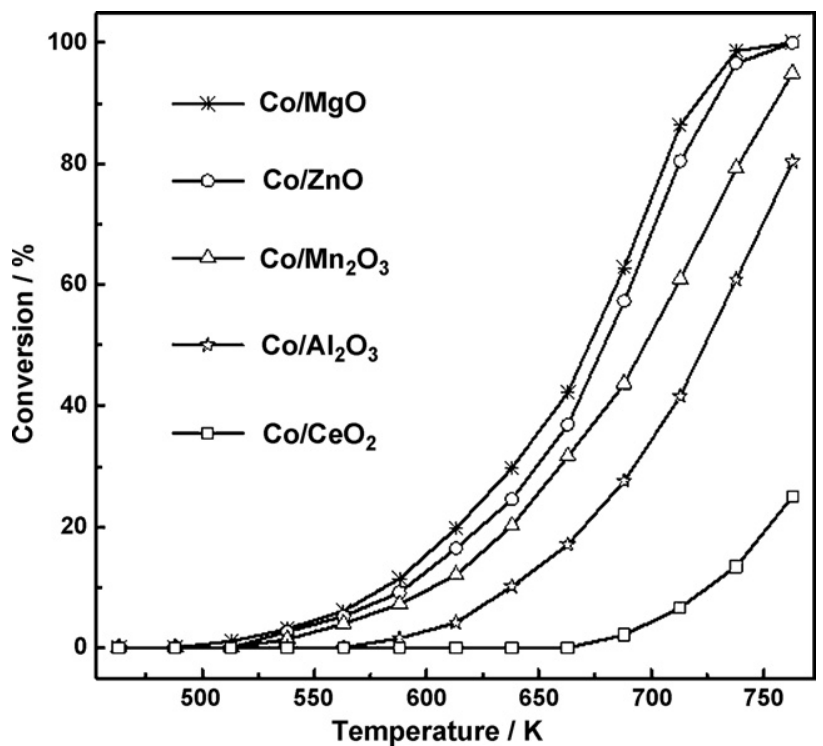

Fig. 5. Catalytic activities for $\mathrm{N}_{2} \mathrm{O}$ decomposition on Co-based catalysts. Reaction condition: $0.1 \mathrm{~g}$ catalyst, $1 \% \mathrm{~N}_{2} \mathrm{O}$ and the balance $\mathrm{He}, \mathrm{GHSV}=30000 \mathrm{~h}^{-1}$. same active cobalt species operates during $\mathrm{N}_{2} \mathrm{O}$ catalytic decomposition over pure $\mathrm{CO}_{3} \mathrm{O}_{4}$ and $\mathrm{Co} / \mathrm{MgO}$ samples with cobalt loadings of $5-15 \%$. Based on the XRD and XPS results, highly dispersed $\mathrm{Co}_{3} \mathrm{O}_{4}$ in the $\mathrm{MgO}$ matrices should be the active sites for $\mathrm{N}_{2} \mathrm{O}$ decomposition over $\mathrm{Co} / \mathrm{MgO}$ catalysts. As for pure $\mathrm{CO}_{3} \mathrm{O}_{4}$, considering the much low BET surface $\left(25.7 \mathrm{~m}^{2} / \mathrm{g}\right)$, only a small part of active sites can take part in the catalytic reaction and the activity was severely limited. As a result, the activity of pure $\mathrm{Co}_{3} \mathrm{O}_{4}$ is only a little higher than other supported catalysts (seen in Figs. 5 and 6).

In the tail gas of nitric acid plant, some typical components (i.e. $\mathrm{O}_{2}$, NO and $\mathrm{H}_{2} \mathrm{O}$ ) coexist with $\mathrm{N}_{2} \mathrm{O}$ and it is very important to clarify their effects on $\mathrm{N}_{2} \mathrm{O}$ decomposition. As seen in Fig. 8 the presence of $5 \% \mathrm{O}_{2}$ in the reaction system shows some mild negative effect on $\mathrm{N}_{2} \mathrm{O}$ decomposition. For example, $\mathrm{N}_{2} \mathrm{O}$ conversion was decreased by about $10 \%$ in $600-700 \mathrm{~K}$. Compared to oxygen, $\mathrm{H}_{2} \mathrm{O}$ shows more serious negative effect on $\mathrm{N}_{2} \mathrm{O}$ decomposition. The temperature

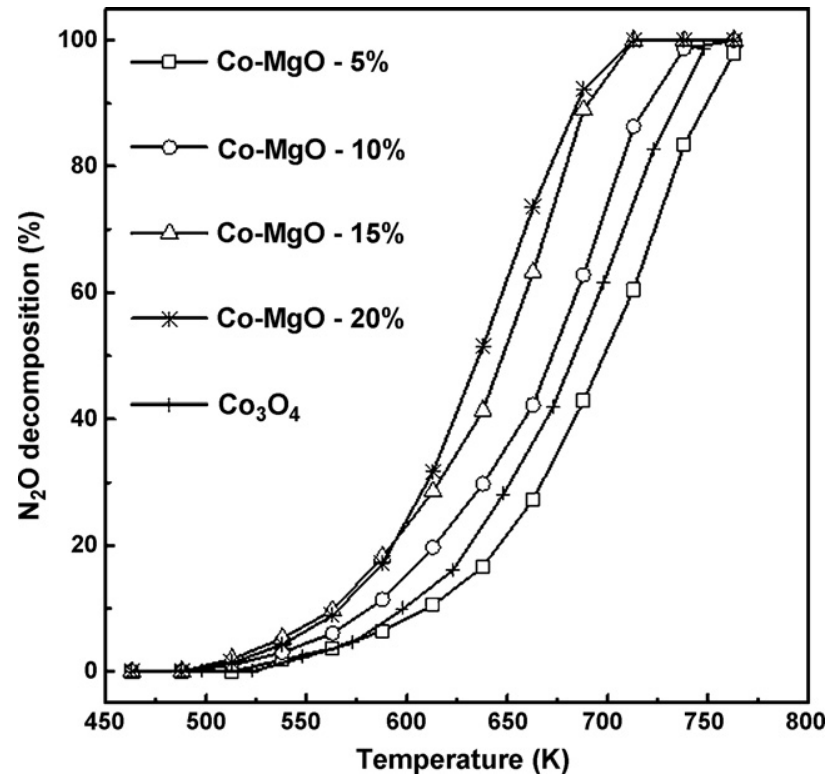

Fig. 6. Catalytic activities for $\mathrm{N}_{2} \mathrm{O}$ decomposition on $\mathrm{Co}_{3} \mathrm{O}_{4}$ and $\mathrm{Co} / \mathrm{MgO}$ with different cobalt loadings. Reaction conditions: $0.1 \mathrm{~g}$ catalyst, $1 \% \mathrm{~N}_{2} \mathrm{O}$ and the balance $\mathrm{He}, \mathrm{GHSV}=30000 \mathrm{~h}^{-1}$. 


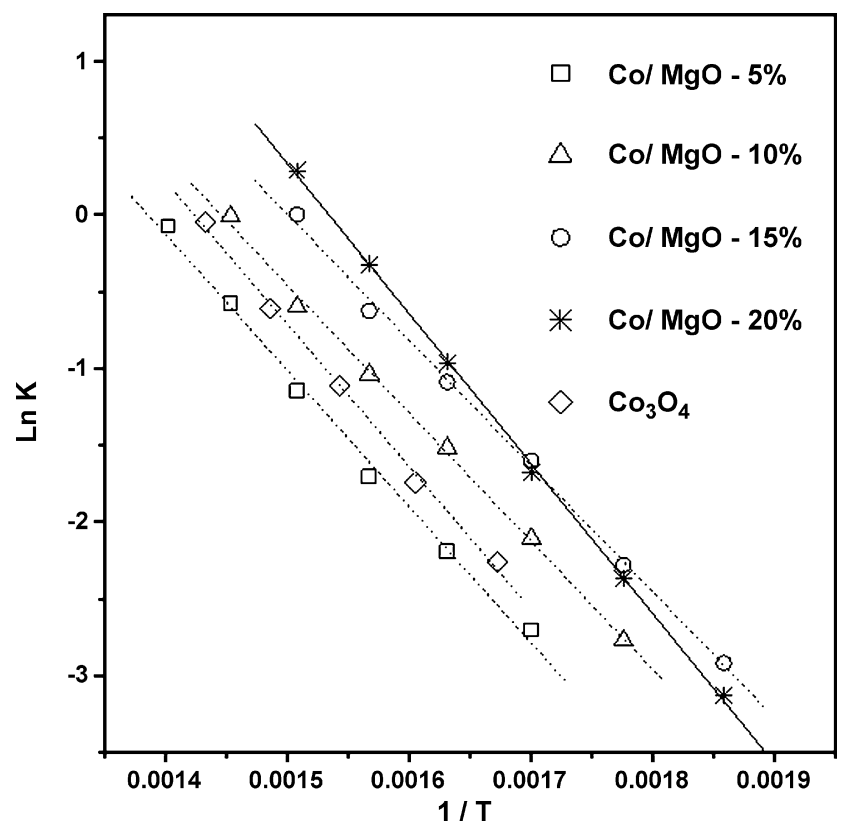

Fig. 7. Arrhenius plot of $\mathrm{N}_{2} \mathrm{O}$ decomposition on $\mathrm{Co} / \mathrm{MgO}$ with different cobalt loadings.

with $100 \% \mathrm{~N}_{2} \mathrm{O}$ conversion increases at about $50 \mathrm{~K}$ in the presence of $2 \% \mathrm{H}_{2} \mathrm{O}$. Similar to $\mathrm{O}_{2}$ and $\mathrm{H}_{2} \mathrm{O}$, NO also shows negative activity for $\mathrm{N}_{2} \mathrm{O}$ decomposition. The inhibition effect of other components $\left(\mathrm{O}_{2}, \mathrm{H}_{2} \mathrm{O}\right.$ and $\left.\mathrm{NO}\right)$ on $\mathrm{N}_{2} \mathrm{O}$ decomposition is presumably related to their competitive adsorption and reaction on cobalt sites, which reduces $\mathrm{N}_{2} \mathrm{O}$ chemisorption and inhibits the total conversion rate. It is also seen the negative effects of $\mathrm{O}_{2}, \mathrm{H}_{2} \mathrm{O}$ and $\mathrm{NO}$ may be accumulative. Under simulated conditions of tail gas from nitric acid plant ( $1 \% \mathrm{~N}_{2} \mathrm{O}, 5 \% \mathrm{O}_{2}, 2 \% \mathrm{H}_{2} \mathrm{O}$, and $800 \mathrm{ppm} \mathrm{NO}$ ), $50 \%$ and $100 \%$ $\mathrm{N}_{2} \mathrm{O}$ conversion can be obtained at 725 and $800 \mathrm{~K}$, respectively. The high activity of $\mathrm{Co} / \mathrm{MgO}-15 \%$ at sustainable temperature makes it promising catalyst for $\mathrm{N}_{2} \mathrm{O}$ decomposition.

The catalyst durability is a very important criterion to be considered for its real application. Remarkably, Co/MgO-15\% sample

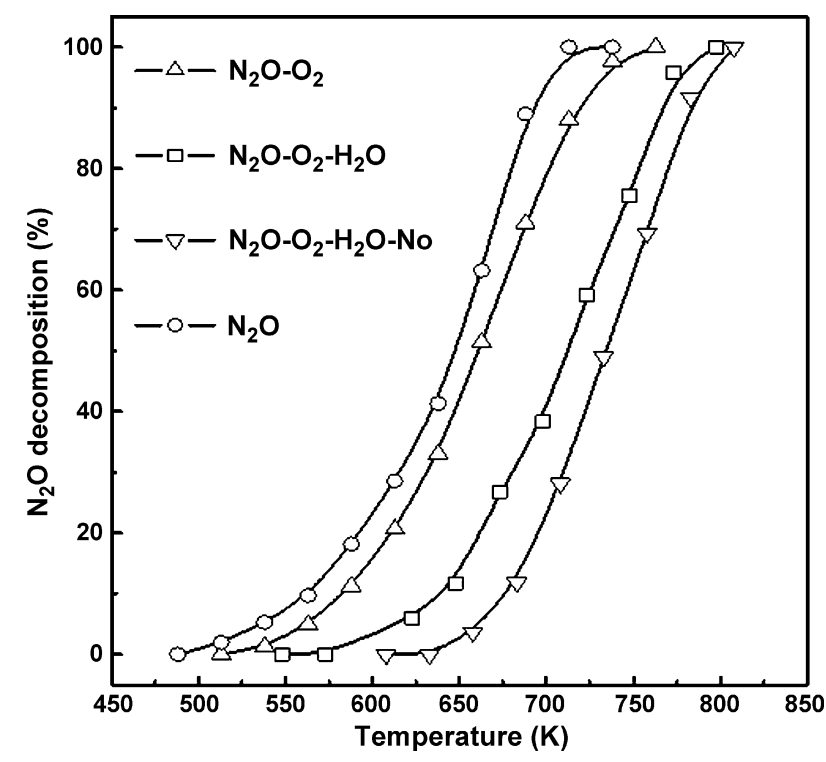

Fig. 8. Effect of $\mathrm{O}_{2}, \mathrm{H}_{2} \mathrm{O}$ and $\mathrm{NO}$ in the stream on $\mathrm{N}_{2} \mathrm{O}$ conversion over Co/MgO-15\% catalyst. Reaction conditions: $0.1 \mathrm{~g}$ catalyst, $1 \% \mathrm{~N}_{2} \mathrm{O}, 0$ or $5 \% \mathrm{O}_{2}, 0$ or $2 \% \mathrm{H}_{2} \mathrm{O}, 0$ or $800 \mathrm{ppm}$ NO, balance He, GHSV $=30000 \mathrm{~h}^{-1}$.

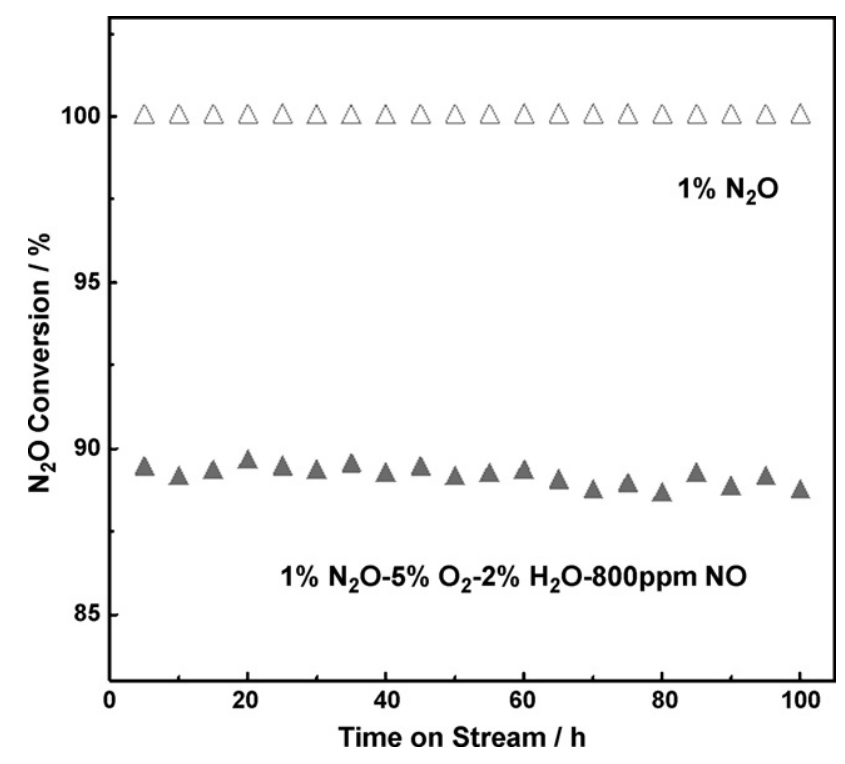

Fig. 9. Time-on-stream behavior of $\mathrm{Co} / \mathrm{MgO}-15 \%$ catalyst for the decomposition of $\mathrm{N}_{2} \mathrm{O}$ at $773 \mathrm{~K}$ under two different conditions. Reaction conditions: $0.25 \mathrm{~g}$ catalyst, $\mathrm{GHSV}=30000 \mathrm{~h}^{-1}$

shows high durability not only under the simple condition of $\mathrm{N}_{2} \mathrm{O} / \mathrm{He}$ but also under the simulated conditions of tail gas from nitric acid plant. As shown in Fig. 9, there is no obvious evidence of catalytic activity lost over $100 \mathrm{~h}$ at $773 \mathrm{~K}$. The good durability of $\mathrm{Co} / \mathrm{MgO}-15 \%$ is in sharp contrast to the case of other Co-based catalysts [24]. It is found that the structure of $\mathrm{Co} / \mathrm{MgO}$ sample (XRD patterns not shown here) does not change after reaction for $100 \mathrm{~h}$.

\section{Conclusion}

The catalytic decomposition of $\mathrm{N}_{2} \mathrm{O}$ over a series of supported cobalt catalysts prepared by co-precipitation method was studied. The alkaline $\mathrm{MgO}$, with strong electron donation effect, appears to be the best support for the active phase of cobalt species for this reaction. The optimal cobalt loading of $\mathrm{Co} / \mathrm{MgO}$ is $15 \%$, and active phase of cobalt species exists in the form of $\mathrm{Co}_{3} \mathrm{O}_{4}$ highly dispersed in the matrices of $\mathrm{MgO}$, which is further confirmed to be the active sites for $\mathrm{N}_{2} \mathrm{O}$ decomposition. $\mathrm{Co} / \mathrm{MgO}-15 \%$ exhibits quite good $\mathrm{N}_{2} \mathrm{O}$ decomposition activity and durability under simulated conditions of tail gas from nitric acid plant, which provides us a promising catalyst for the control of greenhouse gas $\mathrm{N}_{2} \mathrm{O}$ from anthropogenic sources.

\section{Acknowledgements}

This work was financially supported by National Natural Science Foundation of China (20725723, and 20703057) and National Basic Research Program of China (2004CB719500).

\section{References}

[1] J.T. Houghton, IPCC Third Assessment Report: Climate Change, 2001, http://www.ipcc.ch/pub/reports.htm.

[2] J. Pérez-Ramírez, Prospects of $\mathrm{N}_{2} \mathrm{O}$ emission regulations in the European fertilizer industry, Appl. Catal. B 70 (2007) 31-35.

[3] V. Boissel, S. Tahir, C.A. Koh, Catalytic decomposition of $\mathrm{N}_{2} \mathrm{O}$ over monolithic supported noble metal-transition metal oxides, Appl. Catal. B 64 (2006) 234-242.

[4] A. Bueno-López, I. Such-Basáñez, C. Salinas-Martínez de Lecea, Stabilization of active $\mathrm{Rh}_{2} \mathrm{O}_{3}$ species for catalytic decomposition of $\mathrm{N}_{2} \mathrm{O}$ on La-, $\mathrm{Pr}$-doped $\mathrm{CeO}_{2}$, J. Catal. 244 (2006) 102-112.

[5] J. Haber, M. Nattich, T. Machej, Alkali-metal promoted rhodium-on-alumina catalysts for nitrous oxide decomposition, Appl. Catal. B 77 (2008) 278-283. 
[6] L.Z. Gao, C.T. Au, Studies on the decomposition of $\mathrm{N}_{2} \mathrm{O}$ over $\mathrm{Nd}_{2} \mathrm{CuO}_{4}$, $\mathrm{Nd}_{1.6} \mathrm{Ba}_{0.4} \mathrm{CuO}_{4}$ and $\mathrm{Nd}_{1.8} \mathrm{Ce}_{0.2} \mathrm{CuO}_{4}$, J. Mol. Catal. A 168 (2001) 173-186.

[7] S. Alini, F. Basile, S. Blasioli, C. Rinaldi, A. Vaccari, Development of new catalysts for $\mathrm{N}_{2} \mathrm{O}$-decomposition from adipic acid plant, Appl. Catal. B 70 (2007) 323-329.

[8] M. Santiago, J. Pérez-Ramírez, Decomposition of $\mathrm{N}_{2} \mathrm{O}$ over hexaaluminate catalysts, Environ. Sci. Technol. 41 (2007) 1704-1709.

[9] L. Obalová, K. Jirátová, F. Kovanda, M. Valášková, J. Balabánová, K. Pacultová, Structure-activity relationship in the $\mathrm{N}_{2} \mathrm{O}$ decomposition over $\mathrm{Ni}-(\mathrm{Mg})-\mathrm{Al}$ and $\mathrm{Ni}-(\mathrm{Mg})-\mathrm{Mn}$ mixed oxides prepared from hydrotalcite-like precursors, J. Mol. Catal. A: Chem. 248 (2006) 210-219.

[10] N. Russo, D. Mescia, D. Fino, G. Saracco, V. Specchia, $\mathrm{N}_{2} \mathrm{O}$ decomposition over perovskite catalysts, Ind. Eng. Chem. Res. 46 (2007) 4226-4231.

[11] G.D. Pirngruber, The surface chemistry of $\mathrm{N}_{2} \mathrm{O}$ decomposition on ironcontaining zeolites, J. Catal. 219 (2003) 456-463.

[12] J.A.Z. Pieterse, S. Booneveld, R.W. van den Brink, Evaluation of Fe-zeolite catalysts prepared by different methods for the decomposition of $\mathrm{N}_{2} \mathrm{O}$, Appl. Catal B 51 (2004) 215-228.

[13] I. Melián-Cabrera, C. Mentruit, J.A.Z. Pieterse, R.W. van den Brink, G. Mul, F. Kapteijn, J.A. Moulijn, Highly active and stable ion-exchanged Fe-ferrierite catalyst for $\mathrm{N}_{2} \mathrm{O}$ decomposition under nitric acid tail gas conditions, Catal. Commun. 6 (2005) 301-305.

[14] E.V. Kondratenko, J. Pérez-Ramírez, Mechanism and kinetics of direct $\mathrm{N}_{2} \mathrm{O}$ decomposition over Fe-MFI zeolites with different iron speciation from temporal analysis of products, J. Phys. Chem. B 110 (2006) 22586-22595.

[15] L.D. Li, Q. Shen, J.J. Yu, Z.P. Hao, Z.P. Xu, G.Q. Max Lu, Fe-USY zeolite catalyst for effective decomposition of nitrous oxide, Environ. Sci. Technol. 41 (2007) 7901-7906.

[16] R.S. da Cruz, A.J.S. Mascarenhas, H.M.C. Andrade, Co-ZSM-5 catalysts for $\mathrm{N}_{2} \mathrm{O}$ decomposition, Appl. Catal. B 18 (1998) 223-231.

[17] Z.H. Zhu, G.Q.M. Lu, Y.H. Zhuang, D.X. Shen, A comparative study of $\mathrm{N}_{2} \mathrm{O}$ conversion to $\mathrm{N}_{2}$ over $\mathrm{Co} / \mathrm{AC}$ and $\mathrm{Cu} / \mathrm{AC}$ catalysts, Energy Fuel 13 (1999) 763-772.

[18] S. Kannan, C.S. Swamy, Catalytic decomposition of nitrous oxide over calcined cobalt aluminum hydrotalcites, Catal. Today 53 (1999) 725-737.

[19] U. Chellam, Z.P. Xu, H.C. Zeng, Low-temperature synthesis of $\mathrm{Mg}_{x} \mathrm{Co}_{1-x} \mathrm{Co}_{2} \mathrm{O}_{4}$ spinel catalysts for $\mathrm{N}_{2} \mathrm{O}$ decomposition, Chem. Mater. 12 (2000) 650-658.
[20] L. Yan, T. Ren, X.L. Wang, D. Ji, J.S. Suo, Catalytic decomposition of $\mathrm{N}_{2} \mathrm{O}$ over $\mathrm{M}_{x} \mathrm{Co}_{1-x} \mathrm{Co}_{2} \mathrm{O}_{4}(\mathrm{M}=\mathrm{Ni}, \mathrm{Mg})$ spinel oxides, Appl. Catal. B 45 (2003) 85-90.

[21] N. Russo, D. Fino, G. Saracco, V. Specchia, $\mathrm{N}_{2} \mathrm{O}$ catalytic decomposition over various spinel-type oxides, Catal. Today 119 (2007) 228-232.

[22] L. Obalová, K. Pácultová, F. Kovanda, K. Pacultová, Z. Lacný, Z. Mikulová, Catalytic decomposition of nitrous oxide over catalysts prepared from $\mathrm{Co} / \mathrm{Mg}-\mathrm{Mn} / \mathrm{Al}$ hydrotalcite-like compounds, Appl. Catal. B 60 (2005) 289-297.

[23] L Obalová, K. Pácultová, J. Balabánová, K. Jirátová, Z Bastl, M. Valášková, Z Lacný, F. Kovanda, Effect of $\mathrm{Mn} / \mathrm{Al}$ ratio in Co-Mn-Al mixed oxide catalysts prepared from hydrotalcite-like precursors on catalytic decomposition of $\mathrm{N}_{2} \mathrm{O}$, Catal. Today 119 (2007) 233-238.

[24] F. Kapteijn, J. RodriguezMirasol, J.A. Moulijn, Heterogeneous catalytic decomposition of nitrous oxide, Appl. Catal. B 9 (1996) 25-64.

[25] A. Cimino, F. Pepe, Activity of cobalt ions dispersed in magnesium oxide for the decomposition of nitrous oxide, J. Catal. 25 (1972) 362-377.

[26] R.S. Drago, K. Jurczyk, N. Kob, Catalyzed decomposition of $\mathrm{N}_{2} \mathrm{O}$ on metal oxide supports, Appl. Catal. B 13 (1997) 69-79.

[27] G.D. Pirngruber, L. Frunz, J.A.Z. Pieterse, The synergy between Fe and Ru in $\mathrm{N}_{2} \mathrm{O}$ decomposition over FeRu-FER catalysts: a mechanistic explanation, J. Catal. 243 (2006) 340-349.

[28] S. Abelló, J. Pérez-Ramírez, Steam activation of Mg-Al hydrotalcite. Influence on the properties of the derived mixed oxides, Micropor. Mesopor. Mater. 96 (2006) 102-108.

[29] J.C. Dupin, D. Gonbeau, P. Vinatier, A. Levasseur, ematic XPS studies of metal oxides, hydroxides and peroxides, Phys. Chem. Chem. Phys. 2(2000)1319-1324.

[30] S. Kaliaguine, A. Van Neste, V. Szabo, J.E. Gallot, M. Bassir, R. Muzychuck, Perovskite-type oxides synthesized by reactive grinding Part I. Preparation and characterization, Appl. Catal. A 209 (2001) 345-358.

[31] J.P. Dacquin, C. Dujardin, P. Granger, Surface reconstruction of supported Pd on $\mathrm{LaCoO}_{3}$ : consequences on the catalytic properties in the decomposition of $\mathrm{N}_{2} \mathrm{O}$, J. Catal. 253 (2008) 37-49.

[32] W.C. Trogler, Physical properties and mechanism of formation of nitrous oxide, Coord. Chem. Rev. 187 (1999) 303-327.

[33] H.S. Zeng, K. Inazu, K. Aika, The working state of the barium promoter in ammonia synthesis over an active-carbon-supported ruthenium catalyst using barium nitrate as the promoter precursor, J. Catal. 211 (2002) 33-41. 